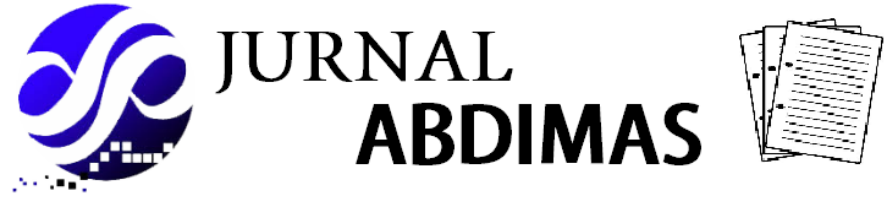

\section{Socialization of the Danger of Drugs to Improve Collage Student's Awareness}

\author{
${ }^{1}$ Wira Jaya Hartono, ${ }^{2}$ Ryone Fachrurozzie S \\ ${ }_{1,2}$ STMIK Dharmapala Riau
}

\author{
Alamat Surat \\ Email: wira.jh@lecturer.stmikdharmapalariau.ac.id*, serdaduphp7@gmail.com
}

Article History:

Diajukan: 20 Januari 2021; Direvisi: 2 Februari 2021; Accepted: 5 Februari 2021

\begin{abstract}
ABSTRAK
Drugs atau obat-obatan bukanlah sesuatu yang berbahaya bila digunakan oleh yang orang ahli, tapi dalam hal ini, seperti sabu-sabu, narkoba, segala turunannya, digunakan oleh mahasiswa secara bebas maka hancurlah kehidupan mahasiswa tersebut. STMIK Dharmapala Riau merupakan sekolah tinggi yang terlokasi di tengah kota dengan interaksi bergaulan yang bermacam-macam, terlebih mayoritas mahasiswa yang belajar disana merupakan pekerja, sehingga hal ini merupakan salah satu lahan yang empuk bagi pengedar menjadikan mereka sebagai konsumen. Oleh karena itu, sosialisasi tentang pendidikan bahaya akan menggunakan narkoba secara harus dilaksanakan untuk menghindari hal-hal dikemudian hari agar tidak terjebak dalam narboka. Dalam pengabdian ini, penulis sebagai penggiat narkoba akan menyampaikan tentang apa itu narkoba, bagaimana mengenai pengguna narkoba, dan cara mengatasi pencandu yang ada ditingkat keluarga, teman dan masyarakat
\end{abstract}

Kata kunci: Bahaya Narkoba, Mahasiswa

ABSTRACT

Drugs are not a dangerous thing if they are used by the experts in medication, but in this case drugs such as crystal meth is consumed by colleagues or university students freely will impact their emotionally and physically. In result it will impact their future to become worse and worse. STMIK Dhamarpala Riau is a college located in central Pekanbaru city. It has freedom of interaction in all aspects, moreover the majority of students are workers. So they become a fresh bait by drug distributors. To prevent that happen and improve their awareness, this is important to give socialization about the danger of drugs in order to avoid bad things occur and they will not trapped in drugs situation. This program is also supported by the National Anti Narcotics Agency of Indonesia. The writer as anti narcotics activators socialize about the definition of drugs, how to recognize drug users, and how to make an anticipation of drug users at the level of family, friends and society.

Keywords: Danger of drugs, University student

\section{ANALISIS SITUASI}

Penelitian ini memiliki landasan undang-undang sebagai berikut Undang - Undang Republik Indonesia No. 35 Tahun 2009 Tentang Narkotika, Eraturan Presiden Nomor 23 Tahun 2010 Tentang Badan Narkotika Nasional, Instruksi Presiden No. 06 Tahun 2018 Tentang Ran P4GN Dan Prekursor Narkotika, Peraturan Kepala BNN RI No: 03 Tahun 2015 Tentang Organisasi Dan Tata Kerja BNN Provinsi Dan BNN Kabupaten Kota.

Potret Permasalahan Narkoba Di Indonesia meliputi geografis yang terbuka menyebabkan Narkoba mudah masuk \& menyebar di seluruh wilayah Indonesia, demografis yang sangat besar (250 
juta jiwa) menjadi pasar potensial peredaran gelap Narkoba, Peredaran gelap Narkoba bukan hanya menyasar orang dewasa dan remaja, melainkan juga anak-anak, Minimnya fasilitas dan aksesibilitas layanan rehabilitasi pecandu narkoba, STIGMA thd Penyalahgunaan narkotika sehingga takut melaporkan diri, Sistem penegakkan hukum yang belum mampu memberikan efek jera kepada penjahat narkoba, modus operandi dan variasi jenis Narkoba yang terus berkembang (41 Jenis Baru), Lapas yang bertransformasi menjadi pusat kendali peredaran gelap narkoba, Kerugian akibat penyalahgunaan Narkoba sekitar 63,1 triliun rupiah (biaya privat \& sosial).

Data dari pusdatin BNN provinsi riau, kasus narkoba selalu meningkat dari tahun ke tahun secara signifikan, mulai dari 4 kasus di tahun 2013 hingga 110 kasus di tahun 2020. Peningkatan tajam ini tidak semerta merta konsumsi obat terlarang menjadi primadona, tetapi juga karena lokasi geografis provinsi riau yang dekat dengan perbatasan Malaysia menjadikan jalur emas distribusi narkoba. Terlebih lagi dengan peningkatan populasi, dan dampak dari virus covid-19 menyebabkan beberapa aspek kehidupan seperti sektor ekonomi menjadi lesu bahkan tutup alias bangkrut. PHK terjadi di segala sektor, pendapatan rendah, sehingga hal ini dimanfaatkan oleh segelintir orang untuk melakukan bisnis narkoba. Dikarenakan letak yang strategis dan kondisi masyarakat tidak stabil membuat bisnis narkoba menjadi subur di provinsi riau.

STMIK Dharmapala Riau adalah sekolah tinggi komputer yang berlokasi di pusat kota, mayoritas mahasiswa belajar di sana merupakan pekerja. Mahasiswa kerja dipagi hari dan kuliah di sore hari. Hal ini membuat setiap mahasiswa memiliki pendapatan. Berdasarkan hasil survei BNN pengguna dari obat-obatan ini 59\% dari kalangan pekerja dan 24\% dari kalangan pelajar atau mahasiswa sehingga total $83 \%$ dari kalangan masyarakat STMIK Dharmapala Riau. Sehingga persentase akan keterlibatan mahasiswa pada narkoba akan tinggi. Oleh karena diperlukan sosialisasi bahaya narkoba sejak dini di kampus.

\section{SOLUSI DAN TARGET}

Solusi dari permasalahan ini yaitu mengadakan sosialisasi tentang bahaya dari penggunaan obat-obatan terlarang dikalangan mahasiswa dan pekerja. Sosialisasi ini dimulai dengan potret permasalahan narkoba di Indonesia, klasifikasi penyalahan narkoba, pengertian narkoba, zat-zat yang paling banyak digunakan jenis narkoba berdasarkan efek terhadap susunan saraf pusat, proses terbentuknya ketergantungan, mengetahui ciri-ciri fisik pengguna, ciri-ciri perilaku, ciri-ciri emosi, faktor penyebab penyalahan narkoba, serta apa yang harus dilakukan bila ada keluarga, kerabat / tetangga sebagai penyalahguna narkoba?, serta ketentuan pidana lebih dari 5 gram.

\section{METODE PELAKSANAAN}

Hasil Dalam kegiatan ini metode yang dilakukan adalah dengan memberikan pemahaman dengan cara sosialisasi kepada warga STMIK Dharmapala Riau tentang peningkatan pemahaman dan kesadaran akan bahaya penggunaan narkoba di lingkungan kampus.

\section{PELAKSANAAN KEGIATAN}

Fungsi dari kegiatan penyuluhan atau sosialisasi ini yaitu 1) menumbuhkan komitmen Diri Seluruh elemen bangsa bertanggung jawab dan berkomitmen menjaga diri, keluarga, kelompok/komunitas, dan lingkungannya dari penyalahgunaan dan peredaran gelap narkoba. 2) Membentuk Regulasi Anti Narkoba yakni penerbitan regulasi pencegahan penyalahgunaan dan peredaran gelap narkoba di tingkat daerah, institusi, kampus, sekolah, dan lingkungan masyarakat, dll. 3) Konsolidasi Kekuatan yaitu Seluruh elemen (pemerintah, swasta, dan masyarakat) berkonsolidasi dan berkontribusi bersama mendukung penanganan narkoba secara massif. 4) Bersih Narkoba Mewujudkan lingkungan masyarakat, pemerintahan, tempat kerja, kampus/sekolah bersih narkoba. 5) Deteksi Dini Penyelenggaraan tes urine secara berkala di lingkungan instansi, organisasi, kampus, sekolah, dan lingkungan masyarakat 


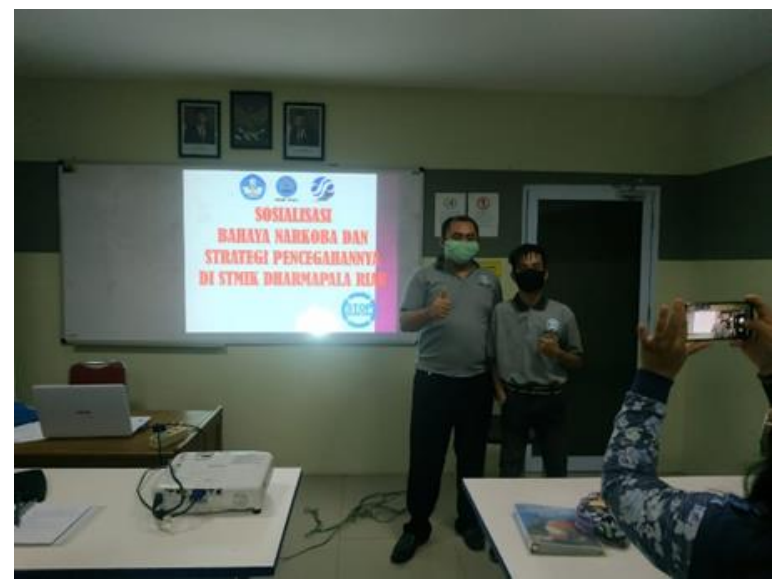

Foto 1: Pembicara / penggiat P4GN STMIK Dharmapala Riau

Kegiatan ini dilaksanakan oleh para Penggiat P4GN. yang merupakan dosen dan mahasiswa STMIK Dharmapala Riau, dan diharapkan semua peserta yang mengikutinya mengajukan mendapat pemahaman dan meningkatnya kesadaran akan bahaya narkoba, sehingga meminimalisir dan meniadakan terjadi jatuhnya korban-korban dari penggunaan narkoba.

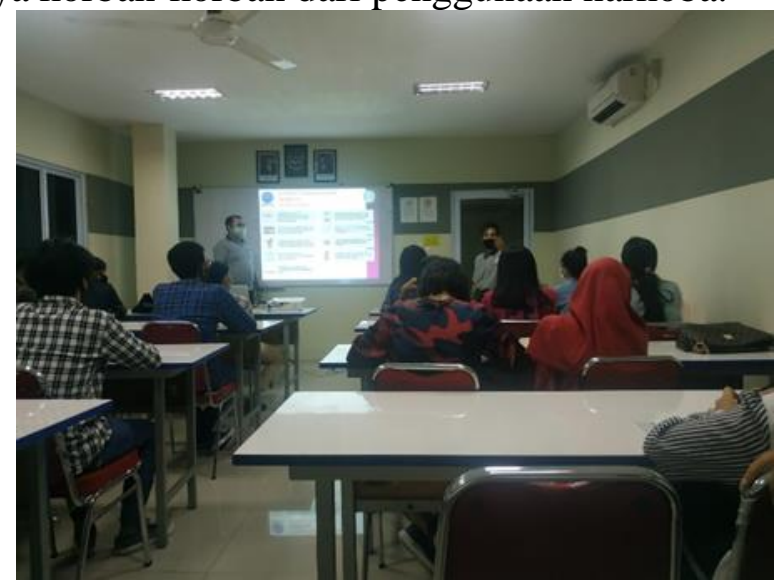

Foto 2: Peserta Sosialisasi

\section{HASIL DAN PEMBAHASAN}

Jumlah peserta yang mengikuti Sosialisasi ini sebanyak 23 mahasiswa yang hadir atas pengumuman yang diberikan oleh pihak kampus. Dari sosialisasi ini dapat diketahui bahwa rata-rata pengetahuan peserta peserta masih sangat minim diketahui dari kuesioner yang diberikan sebelum sosialisasi dimulai.

Pembahasan yang dilaksanakan mulai dari pengertian narkoba \& narkotika, jenis-jenis narkoba dan segala turunannya. Lalu menjelaskan mengenai jenis-jenis narkoba berdasarkan efek pada tubuh dan emosi; proses terbentuknya ketergantungan; strategi dan tujuan penanganan pecandu narkoba, kebijakan dalam penyalahgunaan narkoba.

\section{DISKUSI}

Berdasarkan Sosialisasi dimulai dengan pengertian narkoba, yaitu: bahan/zat yang dapat mempengaruhi kondisi kejiwaan/psikologis seseorang (pikiran, perasaan dan perilakunya) serta dapat menimbulkan ketergantungan fisik dan psikologik, sedangkan narkotika adalah zat atau obat yang berasal dari tanaman/bukan baik sintetis maupun semi sintetis yang dapat menyebabkan penurunan/perubahan kesadaran, hilangnya rasa, mengurangi sampai menghilangkan rasa nyeri, dan dapat menimbulkan ketergantungan. Narkotika dapat dibedakan menjadi 3 golongan, yaitu Golongan I, hanya untuk pengembangan ilmu pengetahuan Tidak untuk terapi, ketergantungan kuat seperti Heroin, Kokain dan Ganja Golongan II, pilihan Terakhir untuk terapi Ketergantungan kuat tetapi 
kurang dari gol. I seperti Morfin, Petidin dan Golongan III yaitu sering untuk therapy Ketergantungan lebih ringan seperti codein.

Kemudian dilanjutkan dengan pengertian dari psikotropika adalah zat atau obat, baik alamiah maupun sintetis bukan Narkotika, yang berkhasiat psikoaktif melalui pengaruh selektif pada susunan saraf pusat yang menyebabkan perubahan khas pada aktivitas mental dan perilaku. Psikotropika dibedakan dalam 4 golongan yakni 1) Golongan I Hanya untuk pengembangan ilmu pengetahuan Tidak untuk Terapi, ketergantungan kuat seperti Ecstasy, MDMA, LSD. 2) Golongan II Bisa untuk terapi, tetapi pilihan terakhir Ketergantungan tinggi tetapi kurang dari gol I sebagai contoh: Amfetamin, metilfenidat (Ritalin), metakualon. 3) Golongan III Sering untuk terapi, ketergantungan sedang sebagai contoh: Fenobarbital, flunitrazepam. 4) Golongan IV Untuk terapi, ketergantungan ringan seperti Diazepam, klobazam, bromazepam.

Bahan atau zat selain Narkotika dan Psikotropika yang dapat juga mempengaruhi psikoaktif tubuh manusia dan dapat menyebabkan kecanduan. Diantaranya Minuman alkohol, Zat Inhalasi/LEM, dan Nikotin/Rokok. Ada beberapa Jenis Narkoba berdasarkan efek terhadap susunan saraf pusat, yaitu 1) stimulant contohnya amfetamin, metamfetamin atau biasa disebut shabu dan Kristal. 2) Depresan contohnya alcohol, benzodiazepine, Opium, morfin, kodein. Dari jenis ini bisa menimbulkan efek seperti ngantuk, kelelahan, penurunan fungsi kognitif dan memori, berkeringat, gelisah, sulit tidur dan sulit berkonsentrasi. 3) Halusinogen contohnya ekstasi, mushroom, bunga kecubung memiliki efek berupa menghasilkan satu spektrum pengalaman sensor yang terdistorsi serta mempengaruhi mood dan proses berpikir.

Proses terbentuknya ketergantungan narkoba, melalui Kompromi mau bergaul d pemakai narkoba lalu diawali dengan coba-coba(segan menolak teman) 3. Toleransi Pemakaian sosial (hanya saat bergaul) -Pemakaian situasional (saat kesal, sedih, kecewa, ada mslh) 4, Kebiasaan pemakaian jadi semakin sering (akan meningkat menjadi sering pakai tidak perlu dipengaruhi atau sedang bermasalah) 5, Puncaknya tahap ketergantungan Bila tidak pakai sakau kerusakan pada organ tubuh lalu meninggal.

Ciri - ciri fisik yaitu berat badan turun gratis, mata terlihat cekung dan merah, muka pucat dan bibir kehitam-hitaman, tangan penuh dengan bintik-bintik merah, seperti bekas gigitan nyamuk dan ada tanda bekas luka, buang air besar \& kecil kurang lancar. Disamping itu dari segi ciri - ciri perilaku seperti malas dan sering melupakan tanggung jawab \& tugas-tugas rutinnya, sikap tidak peduli \& jauh dari keluarga, suka mencuri uang di rumah, sekolah atau tempat pekerjaan \& menggadaikan barang-barang berharga di rumah dan selalu kehabisan uang. Ciri-ciri emosi seperti sangat sensitif dan cepat bosan, membangkang bila ditegur atau dimarahi, emosinya naik turun \& tdk ragu utk memukul orang atau berbicara kasar pada anggota keluarga atau orang di sekitarnya, nafsu makan tidak menentu.

Adapun strategi dan tujuan kegiatan ini yaitu membentuk komitmen diri. Seluruh elemen bangsa bertanggung jawab dan berkomitmen menjaga diri dan berkomitmen menjaga diri, keluarga, kelompok/komunitas, dan lingkungannya dari penyalahgunaan dan peredaran gelap narkoba. Seterusnya pembentukan bentuk regulasi anti narkoba dengan penerbitan regulasi pencegahan penyalahgunaan dan peredaran gelap narkoba di tingkat institusi kampus, sekolah, lingkungan dan masyarakat. Meningkatkan konsolidasi kekuatan seluruh elemen baik itu pemerintah, swasta dan masyarakat dengan berkonsolidasi dan berkontribusi bersama mendukung penanganan narkoba secara masif. Dengan mewujudkan lingkungan kampus yang bebas dari narkoba serta melakukan deteksi secara dini.

Kebijakan Terhadap Penyalahgunaan Narkoba terdapat 2 model pendekatan yaitu penyalahgunaan narkoba yang secara sukarela melaporkan diri ke IPWL atau dilaporkan oleh anggota keluarga tidak akan dituntut pidana. Penyalahgunaan narkoba yang tidak melaporkan diri ke IPWL dapat ditangkap aparat dan akan diproses hukum.

Kesimpulan dari sosialisasi ini yaitu meningkatkan ada kesadaran bahaya narkoba serta menunjukkan menghilangkan kebiasaan "ketagihan" adalah perjuangan seumur hidup, mengakibatkan Resiko Kehilangan Pekerjaan di depan mata, mencoreng nama baik institusi tempat 
bekerja, anak dan istri terabaikan, keluarga berantakan, karir dan masa depan hancur, dapat menyebabkan terjadinya kecelakaan kerja, menyebabkan kerugian materil bagi institusi tempat bekerja (contoh: penggelapan uang perusahaan, dan lain-lain)

\section{KESIMPULAN}

Dari hasil sosialisasi ini dapat disimpulkan bahwa masih banyak mahasiswa belum memahami akan bahaya dari narkoba dan juga cara pencegahannya. Selama ini mahasiswa hanya mendengar tentang tentang bahayanya saja tanpa mengetahui cara menyelesaikan masalah tersebut. Sosialisasi melalui Penggiat P4GN merupakan langkah yang tepat agar setiap institusi bisa langsung melaksanakan sosialisasi Pemberantasan Penyalahgunaan dan Peredaran Gelap Narkotika (P4GN) di wilayahnya masing-masing sehingga mengurangi resiko yang akan dihadapi mahasiswa dan institusi.

\section{PENGAKUAN}

Dalam kegiatan pengabdian ini penulis mengucapkan terima kasih kepada Ketua Badan Narkotika Nasional Provinsi Riau yang sudah melantik penulis sebagai penggiat P4GN dan Ketua STMIK Dharmapala Riau yang telah memfasilitasi penulis dalam memberikan penyuluhan kepada mahasiswa. Serta kepada semua mahasiswa yang bersedia hadir dalam memenuhi agenda sosialisasi ini.

\section{DAFTAR PUSTAKA}

Abudi, R., \& Irwan. (2015). Peningkatan pemahaman tentang pencegahan dan penanggulangan narkoba dan HIV AIDS melalui pelatihan kader pada remaja Gorontalo. Gorontalo: Universitas Negeri Gorontalo.

DAMANIK, Chrisyen. (2020) Upaya Peningkatan Pengetahuan Remaja Melalui Kegiatan Penyuluhan Kesehatan Mengenai Bahaya Penggunaan Narkoba Di Kalangan Remaja. Pengabdian Masyarakat, [S.1.], v. 1, n. 2, aug. 2020.

Hawari, D. (2009). Penyalahgunaan ketergantungan Naza (Narkotika, alkohol dan bahan adiktif). Jakarta: FKUI.

Nursyifa, A. (2020). Pencegahan Perilaku Menyimpang Akibat Penyalahgunaan Narkoba pada Remaja Millenial di Pulau Untung Jawa. Jurnal Pengabdian Pada Masyarakat, 5(4), 11101121. https://doi.org/10.30653/002.202054.567Kusno Adi, 2009, Kebijakan Kriminal Dalam Penanggulangan Tindak Pidana Narkotika Oleh Anak, UMM Press, Malang

Salatun, Riswan \& Risno Mina. (2019). Penyuluhan Narkoba Sebagai Upaya Preventif Peredaran Gelap Narkoba Di Masyarakat. Monsu'Ani Tano: Jurnal Pengabdian Masyarakat ISSN: e_2615-5737 p_2620-4347 Vol.2 No.1 https://doi.org/10.32529/tano.v2i1.223

Wijoyo, H., \& Haudi, H. (2021, January). PENYULUHAN TEKNIK PEMASARAN KERUPUK RASA JENGKOL "DONG DONG SNACK" PEKANBARU. In PROSIDING SENANTIAS: Seminar Nasional Hasil Penelitian dan Pengabdian kepada Masyarakat (Vol. 1, No. 1, pp. 643-650).

Wijoyo, H. (2020). Socialization Of The Accreditation Asessment System (SISPENA) Of The National Accreditation Board For Early Childhood Education (PAUD) And Non Formal Education (PNF) In Bengkalis, Riau Province. Jurnal Humanities Pengabdian Kepada Masyarakat, 1(1), 103-111.

Wijoyo, H., Haudi, H., Ariyanto, A., Sunarsi, D., \& Akbar, M. F. (2020). Pelatihan Pembuatan Konten Digital Marketing Dalam Meningkatkan Kompetensi Mahasiswa (Pengabdian Kepada Masyarakat Kerjasama Antar Kampus). IKRA-ITH ABDIMAS, 3(3), 169-175. 
Wijoyo, H. (2020). Sosialiasi Sistem Penilaian Akreditasi (SisPenA) Badan Akreditasi Nasional Pendidikan Anak Usia Dini (PAUD) dan Pendidikan Non Formal (PNF) di Kecamatan Bantan, Kabupaten Bengkalis, Propinsi Riau. ARBITRASE: Journal of Economics and Accounting, 1(1), 7-10.

https://puslitdatin.bnn.go.id/portfolio/data-statistik-kasus-narkoba/ 